\title{
Geopolitical Storymaking About Tonga and Fiji: How media fooled people to believe Ma'afu wanted Lau
}

\begin{abstract}
Just when Tongan Democratic Party leader 'Akilisi Pohiva stumped the public by saying he admired Fiji's Prime Minister Frank Bainimarama because "he has been able to make things happen and take development to the people," the Government of Tonga's Minister for Lands, Lord Ma'afu, came right out of the blue and trumped him (Tonga Daily News, 2014a, 2014b). Ma'afu topped Pohiva at causing public bamboozlement.

By this, Pohiva was the progenitor of Tonga's thirty year old pro-democracy movement. Why would he over romanticise about the former military commodore Frank Bainimarama, the hard-line originator of Fiji's third coup to take place in a period of twenty eight years? Pohiva's swinging politics from democracy in Tonga to an overthrow of democracy in Fiji baffled readers (Naidu, 2014; Graue, 2014). But Ma'afu took centre stage as the show stopper.

Momentarily, people were gobsmacked and did not know what to make of him. Was Tonga's Minister for Lands and Survey who was a senior noble in the Tu'ivakano cabinet courting mischief or dead serious? Fiji's permanent secretary for foreign affairs Amena Yauvoli was certain, we "would just have to wait for the Tongan government's proposal" (Tonga Daily News, 2014a). But as Tongan journalist Kalafi Moala put it, "they will be waiting for a very long time" on that geopolitical front (Moala, 2014).

Teena Brown Pulu has a PhD in anthropology from the University of Waikato. She is a senior lecturer in Pacific development at AUT University. Her first book was published in 2011, Shoot the Messenger: The report on the Nuku'alofa reconstruction project and why the Government of Tonga dumped it.
\end{abstract}


This essay explores the geopolitical storymaking about Tonga and Fiji instigated by Tonga Daily News publishing online that Lord Ma'afu had said, "In good faith I will propose to the Minister of Foreign Affairs in Fiji that they can have Minerva Reef and we get Lau in return" (Tonga Daily News, 2014a). The very thought of drawing up a new map instantly ignited outrage from Fijian readers. How then, might Tonga and Fiji's argument over ownership of the Minerva Reefs play out this time around? Could the region's geopolitical atlas ever be imagined differently when its cartography was permanently cemented to the era of Western European colonial empire? When the media fooled people to believe Lord Ma'afu wanted the Lau Islands for the Minerva Reefs, what did this signal about how news sites can manoeuver shock advertising and manipulate what politicians say to up their ratings?

\section{The Ma'afu set up}

My critical reading of the storymaking about Lord Ma'afu is that its inventor, Iliesa Tora, should have fronted up, owned his penmanship, and put his money where his mouth is, seeing he had given himself the part of a news breaking journalist. But he declined to name himself explicitly as the author of the news item, Lord Ma'afu wants Lau for Minerva Reef, published online at the Tonga Daily News website on July 3rd 2014. That spoke volumes about Tora the reporter. It said, quite demonstrably, he was not a hundred percent willing to own his words and take professional responsibility for his publications, especially if he got his facts terribly wrong and there was absolutely no truth to the political messages he was manufacturing and advertising in internet media.

Lord Ma'afu, Tonga's Minister for Lands and Survey and the noble of Vaini and Tokomololo was who the journalist's handiwork seemed to be taking a shot at. He was out of the country on July 3rd when Tora's story broke, representing 
Tonga at the three-day Oceania 21 meeting which commenced in Noumea, New Caledonia on June 30th 2014 (Noumea Communique, 2014). The Minister for Lands attended on behalf of the Prime Minister Lord Tu'ivakano and was surprised, to say the very least, to learn upon his return home of the story circulating about him in the news.

"My son said I was on the television," exclaimed Lord Ma'afu, showing that he was taken back at the made-up media fiasco (Lord Ma'afu, 2014). At first when I asked him about talking to Iliesa Tora, Lord Ma'afu took a few moments to recall who this journalist might have been, and where on earth he had come up with his whale of a tale stirring up controversy and inciting Fijian readers to erupt angrily. That was telling. It told me straight-up that Tora had gotten Tonga's Minister for Lands all twisted up, or perhaps by a more cynical view, he had twisted the storyline on purpose to peddle his profile for self-promotion.

Tora was an indigenous Fijian national who had reported at the Fiji Sun in Suva before migrating to Tonga. Taking on an editing directorship for the Nuku'alofa based owners of Tonga Daily News, husband and wife Joseph and Olive Ramanlal, he described himself on his Twitter page as a "journalist to the bone" (Tora, 2014b). From the suspect manner under which he had collected conversation morsels to paint a dubious portrait of Lord Ma'afu, it was uncertain whether he was digging up dirt, or had a Fijian bone to pick with the Tongans.

To begin with, there was no media "interview" as Tora wrote in his news piece (Tonga Daily News, 2014a).

Lord Ma'afu, the Noble of Vaini here on Tongatapu, made the comments in an interview with Tonga Daily News here in Nuku'alofa. (My emphasis: Tonga Daily News, 2014a). 
Decisively, Iliesa Tora misled the public to believe he had conducted a formal interview by putting questions to Lord Ma'afu on a topic the minister had agreed to discuss for press release. The journalist did not ask the Tongan Minister for Lands to conduct an interview for him, or answer his questions for the express purpose of publishing in Tonga Daily News. More importantly, the Minister had not consented to giving any such interview and was never consulted by Tora about publishing a statement he did not mean seriously.

The story unfolds that Lord Ma'afu and his table were introduced to Iliesa Tora on June 25th 2014 at a luncheon for Tonga's National Orange Day launch. The Minister was having a drink and talking to guests during the buffet service. Davina House, a licensed bar and restaurant convention centre on Vuna Road in Ma'ufanga was the venue. Maybe Tora fantasised that here was a sitting duck he could squeeze for top-secret government information, as if he was an investigative journalist on the hardened political frontline.

Whatever the reporter's social imaginary, he prodded the Minister about Tonga and Fiji foreign relations while the Minister "had a beer in my hand;" a phrase Lord Ma'afu used to stress he was socialising at a luncheon outside of the ministerial workplace. He joked to the Fijian reporter making inquiries about the Tongan state's relationship with the Fijian neighbour and counterpart. The reflexive comment that Tora caught and branded as a Government of Tonga proposal to exchange the Minerva Reefs for the Lau Islands was a complete gag and by no means intended as a factual proposition.

Jointly promoted by the Talitha Project and the Ministry of Internal Affairs, the event where Lord Ma'afu was first introduced to Fijian reporter Iliesa Tora sought to raise awareness of violence against women and girls worldwide, but more specifically, to address gender-based violence in Tonga (Ministry of Information and Communications, 2014). Highprofile officials in attendance were Tongan cabinet ministers 
and parliamentarians, along with foreign diplomats stationed in Tonga from the Australian, New Zealand, and Japanese governments.

Selected local media outlets were also present such as Tonga Daily News which Tora worked for, and Matangi Tonga operated by longstanding Tongan journalist Pesi Fonua. Why were these independent media operators given priority over others? Perhaps the co-organisers assumed they would report accurately and responsibly on the event's purpose and proceedings, which in turn, would help publicise the cause.

For coverage by Tonga Daily News, this did not appear to be the only news priority on the agenda. By this, the company's website reported three sentences with a photograph at $5.50 \mathrm{pm}$ on June 25th, a few hours after the luncheon had concluded.

Lord Fakafanua, the chief guest at the Orange Day Celebrations at Davina House today said 65\% of cases of violence against women in 2012 was too much.

The day was organised by the Talitha Project and UNDP with the support of the Ministry of Internal Affairs and Women.

Also present at the event at Davina House in Ma'ufanga were Lord Vaea, Lord Ma'afu, Hon Sangster Saulala, Deputy Prime Minister Hon Samiu Vaipulu and members of the diplomatic coprs [sic]. (Tonga Daily News, 2014e).

The following morning on June 26th, a lengthier description of Tonga's National Orange Day launch was published with a series of nine photographs and captions identifying the people pictured. Additional to this, an article centring Lord Ma'afu as the main act popped up the day after on June 27th. It was called, Nobles hold the key says Lord Ma'afu, and Iliesa Tora named himself as the sole author (Tora, 2014a). Off the top of his head, Tora had pieced 
together conversation fragments he could recall about the Minister for Lands from the June 25th luncheon, and made it out to be a pressing matter of current affairs.

While speaking to Tonga Daily News at the Orange Day celebrations, held at the Davina House in Ma'ufanga on June 25, Lord Ma'afu, who has blood ties to Fiji, said Tonga should learn from the Fiji situation as the push for democracy continues here in the Kingdom (Tora, 2014a).

Something sinister unravelled the moment Lord Ma'afu "speaking to Tonga Daily News at the Orange Day celebrations" was disseminated online the morning of June 27th 2014 as newsworthy detail (Tora, 2014a). Six days later, Tora would launch a follow-up piece which again, wilfully used Lord Ma'afu as the lead actor in his story. The journalist was to manipulate a highly politicised conspiracy theory on what Tonga was supposedly scheming behind closed doors to unleash on Fiji. All the while, Tora reeled in readership for Tonga Daily News, getting recognition for breaking a whopping scandal of a tale. Woefully, he achieved nothing more than to create a front-page scoop from thin air by manoeuvring a shock advertising tactic.

Shock advertising in this context describes Iliesa Tora's deliberate employment of an alarming one-liner - In good faith I will propose to the Minister of Foreign Affairs in Fiji that they can have Minerva Reef and we get Lau in return - which the journalist knew would disturb, offend, and enrage iTaukei, meaning indigenous Fijians of the Lau islands (My emphasis; Tonga Daily News, 2014a). Conscious that a tidal wave of Fijian hostility would travel to Tonga targeting Lord Ma'afu who would not be safe from public enmity or able to escape the brunt of bad feeling, what was the motive behind Tora's action? What exactly was the newspaper's justification for inciting wrathful public comments posted on the Tonga 
Daily News website under the ill-reputed article, Lord Ma'afu wants Lau for Minerva Reef?

He's either an idiot or a warmonger, which ever it is he shows his lack of respect in this new age, an insult to some of the Lau natives of Fiji. He has opened a can of shit storm which I hope his bald head would be ready to handle. (Comment 1 posted on Tonga Daily News, 2014a).

Untangling this distorted tale, on midday on July 3rd, Iliesa Tora raised the risky reporting stakes with the second newsflash based on his Ma'afu memoirs titled, Lord Ma'afu wants Lau for Minerva Reef. An instant hit, he had cracked the code of internet recognition by pulling off a performance of dramatic proportion. In one working week by the 8 th of July, the article's characterization on Tonga Daily News website, or quite possibly the character assassination of Lord Ma'afu, rated at 163 likes on Facebook and 12 tweets. Tora tweeted the article to his Twitter page for additional exposure. $\mathrm{He}$ must have had an inkling this outrageous tale would get him cited and reposted on other news sites.

It did exactly that (BBC News, 2014; Gilbert, 2014; Latu, 2014; Radio New Zealand, 2014). Anivesh Gopal of the Fiji Times Online produced three pieces in a space of three-days, which were dedicated to dissing Lord Ma'afu for insulting Fiji and its citizens with an audacious proposition to annex the Lau Islands (Gopal, 2014a, 2014b, 2014c). Suspiciously, Gopal was too quick off the mark in publishing his first article called 'Give Up Lau' on the exact same afternoon that Tora released his July 3rd bombshell. Thus, the plot thickened with the journalist duo (Gopal, 2014a). Gopal of the Fiji Times Online and Tora of Tonga Daily News were in fact political actors who curiously behaved like co-conspirators in a synchronised ploy to make a spectacle out of Lord Ma'afu. 
One can only speculate that the plan went down something like this. It was likely they were colleagues from the Fijian media industry, and that Tora approached Gopal to use his professional connections to the Fijian Government's foreign affairs ministry to solicit a response on the Ma'afu statement, "In good faith I will propose to the Minister of Foreign Affairs in Fiji that they can have Minerva Reef and we get Lau in return" (Tonga Daily News, 2014a). Gopal insinuated in his Fiji Times Online item that he, himself, had gotten hold of Fiji's "Foreign Affairs permanent secretary Amena Yauvoli" for a statement, although the Minister Ratu Inoke Kabuabola was out of the country and unavailable for comment.

No comment could be obtained last night from Foreign Affairs Minister Ratu Inoke Kabuabola, who is in Korea. However, Foreign Affairs permanent secretary Amena Yauvoli said last night the ministry would just have to wait for the Tongan Government's proposal. (Gopal, 2014a).

The twist was a couple of hours before Gopal published online, Tora had put his article on the internet which practically read identical to Gopal's work. These journalists composed scripts that were so strikingly word-for-word similar, a reader might think it was the same piece of writing reposted. Tora even noted the Fiji Times could not get hold of Fiji foreign minister Ratu Inoke Kabuabola for his reaction to what the Tongan Minister for Lands had suggested. However, the newspaper did get the foreign secretary's response.

But Gopal's item had not been published at the time Tora announced over the internet the Fiji Times contacted their government's foreign ministry for a public statement. Iliesa Tora was aware the Fiji Times had followed up on this so-called scoop, and he knew exactly what Anivesh Gopal had written 
for publication. Perceptibly, they were working in cahoots to break the news simultaneously in Tonga and Fiji.

No comment could be obtained last night from Fiji's Foreign Affairs Minister Ratu Inoke Kabuabola, who is in Kora. However, Fiji's Foreign Affairs permanent secretary Amena Yauvoli told the Fiji Times last night the ministry would just have to wait for the Tongan Government's proposal. (Tonga Daily News, 2014a).

Iliesa Tora's headline announced, Lord Ma'afu wants Lau for Minerva Reef in capital, bolded letters for emphasis. A tantalising attention grabber, the descriptor was crafted and calculated to elicit a strong emotional response. Indeed it got that, mainly from the Tonga-Fisi identity group, that is, from people of Tongan and Fijian ancestries. A storyline that appealed to the author, Tora as a Fijian ex-patriate living and working in Tonga deliberately forced Lord Ma'afu's character to play the anti-hero; the villain of a one-act play he had written to provoke the Fijian government into reacting against the Tonga state.

If anyone was playing on words and manipulating emotions to cause an uproar, it was Tora the reporter. He fanned the flames of a conspiracy storyline that could burn out of control and tarnish the fire-starter if he did not exercise fair judgement and honesty in his work. As the editing director of the Tonga Daily News, the newspaper's motto, Balanced and Factual, came under the microscope along with his professional ethics as a self-titled "journalist to the bone" (Tora, 2014b).

Indeed the flammable sentence Iliesa Tora took upon himself to publish - "So in good faith I will propose to the Minister of Foreign Affairs in Fiji that they can have Minerva Reef and we get Lau in return" - could have been a roundabout and near enough utterance that came from Tonga's Minister for Lands. But it was not provably a 
verbatim statement made by Lord Ma'afu in those exact words (Tonga Daily News, 2014a). It was, however, an off the cuff remark meant in jest, which Tora distorted and singled out in Ma'afu wants Lau for Minerva Reef. Building up publicity for reporting from Tonga might have brought personal gain, but printing an imaginary story passed off as fact was chancy business without any guarantee of getting away with it. For there was always the risk of being called out, pulled up, and forced to come clean.

Whether Iliesa Tora's tale was balanced and factual as his newspaper had branded their business, did not matter in the moment of pushing the story out into the public domain. His Ma'afu masterpiece got him noticed. The key message that a Tongan annexation of Fiji was quite on the geopolitical cards became impulsively and uncritically repeated by other news operators who unanimously failed to fact-check with the Government of Tonga if there was a real proposal in the pipeline to trade their Minerva Reefs for Fijis Lau islands. Astonishingly, not one news outlet from Tonga, the Pacific Islands region, or internationally stopped to question whether there was an ounce of verifiable truth in the matter. Even state broadcasters of the United Kingdom and New Zealand governments, $B B C$ and Radio New Zealand International were duped into publishing news summaries on the Tongan Ma'afu scandal that Tora had started.

The Fijian journalist took Lord Ma'afu completely out of context. By removing him from a social conversation of clowning over a drink in a restaurant-bar, the circumstances of joking with a Fijian journalist whom Tonga's Minister for Lands had only just met were cut-out, silenced, and rendered invisible. Iliesa Tora set up his main character to look dodgy and treacherous. Framed as a stand-alone caption to allure a captive audience for Tora's staged act, "In good faith I will propose to the Minister of Foreign Affairs in Fiji that they can have Minerva Reef and we get Lau in return," was designed to shock and create a public fracas. In turn, the journalist 
capitalised on the hullaballoo he purposely created to raise his reputation as a small islands reporter wrenching open a Tongan equivalent to the Watergate scandal, or something thereabouts in magnitude.

If read carefully, the actual crux of Tora's item centred on a historical pattern of political behaviour in which "Tonga and Fiji have had some heated issues on the ownership of the [Minerva] reef" (Tonga Daily News, 2014a). This was the main point Ma'afu had wanted to make through light-hearted humour. Instead, pure invention warped and twisted him. He was no longer himself but the Tongan noble megalomaniac, going about swapping Tonga's Minerva Reefs for Fiji's Lau Islands.

In the end, Tora's storymaking skill had little to do with being balanced and factual. Unwittingly, the story alerted critical attention to the absurdity that in this day and age of easy access internet news, its sellers and spinners could wield conniving and underhanded communication methods in the public domain. The moral of the story? Reporters in Pacific Island states, similar to journalists working for media corporations in wealthy developed countries, possessed the power and agency to fool people into believing half-baked whoppers. To the detriment and demise of ethical journalism, controlling information and upping public ratings functioned simultaneously and were permitted to run riot in the internet media industry without regulation or moral constraint (Tonga Daily News, 2014a).

And here is a piece of my mind. I rest my case.

\section{Unfolding conspiracies}

Of course I am making a Tongan-centric value judgement when I say that I find it difficult, almost impossible to believe that Iliesa Tora did not have the intellectual capacity to comprehend that Lord Ma'afu was kidding him when he said, "In good faith I will propose to the Minister of Foreign Affairs in 
Fiji that they can have Minerva Reef and we get Lau in return" (Tonga Daily News, 2014a). I do not believe my own countrymen and women - Tongan journalists reporting on national politics and regional geopolitics - would witness in person Lord Ma'afu teasing and clowning over a drink during a government luncheon, and interpret this as an authentic media interview of accurate information for print. Were there cultural differences preventing a Fijian journalist in Tonga from recognising the social exchange of banter and mocking humour?

A fellow academic based at a different New Zealand university to where I work at Auckland University of Technology explained to me, "It's a great example of the Margaret Mead approach" (Anonymous Correspondent 2, 2014). An American anthropologist, Mead gained notoriety among Pacific Islander academics for her 1920s fieldwork in Ta'u, the largest island of the Manu'a group of American Samoa. Her approach in a nutshell was to literally interpret interviews with Samoan females in their teenage and young adult years on sexuality and sexual experience as truthful, authentic accounts.

From the fantastic stories given to Mead she deduced it was all part of coming of age in primitive Samoan society for young women to have casual sex with multiple male partners before marriage (Mead, 1928). The anthropologist painted Samoa as a free love society that encouraged young single women to enter into pre-marital sexual relations. What Mead got in her interviews with Samoan girls and women talking about sex was as factual and reliable as the Tongan Lord Ma'afu pulling a Fijian's journalist's leg in a restaurant-bar over annexing the Lau islands in exchange for two underwater reefs named Minerva.

The setting Lord Ma'afu was situated in at the time he conversed with Iliesa Tora comprised of buffet food, alcohol served to guests, and clusters of mainly state bureaucrats and foreign diplomats talking at restaurant tables for a 
Government of Tonga campaign launch to raise national awareness of violence against women. Tonga's Minister for Lands cracked some amusing comebacks to a Fijian journalist questioning him about Tonga and Fiji's geopolitical relations, while in earshot of fellow cabinet ministers, parliamentarians, and foreign diplomats seated and socialising around them. Who in the real world would publish the Minister's comments as a believable newspaper article on the internet? The Margaret Mead of journalism in Pacific Island states?

Another fellow academic based at the university where I am employed illuminated that the kinship tie between Ma'afu, the 19th century Tongan chief who conquered the Lau islands claiming the eastern archipelago as part of Tonga, and the present Lord Ma'afu of Vaini and Tokomololo, would have generated social anxiety. This was "especially [so] for some Fijians who recall the history of Lau and the strong Tongan links," noted my work colleague (Anonymous Correspondent 1, 2014).

The Lau-Minerva swap seemed a very far-fetched story and it is very sad to hear that a reporter put a remark, in jest, into a media article that has been picked up by other commentators (like Pacific Islands Report) as a serious suggestion. Being connected through his family line and the title to the old Ma'afu who was Tui Nayau in the late 19th century would lend a bit of superficial credibility to the suggestion that Lau might become part of Tonga, especially for some Fijians who recall the history of Lau and the strong Tongan links in the 19 century. (Anonymous Correspondent 1, 2014).

Looking closely at Tora's personification of Lord Ma'afu, my colleague's analysis rings a bell. Tightly woven in the two news pieces Tora composed on the Tongan Minister for Lands, the author emphasised a culture-specific identity marker. 
Lord Ma'afu was no run of the mill Tongan noble. He was none other than kinfolk to Ma'afu the Tui Lau. Lord Ma'afu was "named after Ma'afu, the Tongan Prince who waged war on parts of Lau and claimed them for Tonga years ago," penned Tora (Tonga Daily News, 2014a). He "has blood ties to Fiji” (Tora, 2014).

In many ways, this represented the historical narrative that fastened together the past and present persona of Ma'afu - a warlord, an aggressor, a conqueror - and how Lord Ma'afu's characterisation unfurled in Tongan and Fijian commentaries. Remarks posted on news websites and social media embellished Tora's allegation that Lord Ma'afu was executing a takeover of the Lau islands on behalf of Tonga because it was the convenient myth people could trace to a time in the 19th century and make sense of.

Two days after Tora's story broke, Auckland based Tongan Kalino Latu duplicated the message on his internet news site New Zealand Kaniva Pacific in a piece titled, Tonga seeks ownership of Fiji's Lau group (Latu, 2014). The opening sentences forged an immediate association between the past 'Enele Ma'afu of Lau and the present Lord Ma'afu of Vaini and Tokomololo, suggesting that the latter was re-enacting the territorial appropriation deeds of the former.

Lord Ma'afu, Tonga's Minister of Lands and Survey, wants the Lau group to be given to Tonga in exchange for the Minerva Reef. Lord Ma'afu is a descendant of Tongan high chief and warlord, 'Enele Ma'afu, who conquered the islands in about 1986. He eventually declared himself Tu'i Lau or the King of Lau. (Latu, 2014).

The following evening on July 6th, a Tongan reader posted in intricate detail on Latu's website. It was one of two conspiracy sub-plots that Tongan and Fijian consumers of internet news spoke of. Kindled by Tora's theory that Tonga 
was planning a direct provocation to appropriate Fiji's Lau islands, the Tongan observer "believed that the Chiefs of Lau [had] discussed their return to Tonga" in 2007, and were likely to be having a similar conversation now in 2014 (Comment 1 posted in Latu, 2014).

He (Fielakepa) was stating that the Lau Group was part of Tonga until 1925 when the British Government officially requested Tonga to include the "Otu Lau" as part of Fiji. Again this was raised in 2007 by a meeting of the FCC (Fiji Council of Chiefs) that the Chiefs of Lau discussed their return to Tonga. I believed Tevita Mara, the Fotofili (Lau), Foiakau, Tukuitoga, Ulundole, etc knows a lot of this development. (Comment 1 posted in Latu, 2014).

On the same day of July 6th, Gopal's third article on the Ma'afu statement also unravelled a sedition sub-plot where the antagonists were "a chiefly clan in Lau who want someone to become the Tui Nayau," the paramount chief of the Lau islands (Naipote Vere cited in Gopal, 2014c). In this case the discussant was Naipote Vere, a Fijian lawyer based in Lakeba, the provincial capital of Lau.

I suspect that the proposal that is expected to be made by Tonga is the work of a chiefly clan in Lau who want someone to become the Tui Nayau. There is no Tui Nayau right now and the only way that person can become the holder of the title is when Lau becomes a part of Tonga, as he was not here for some time. The common thinking in the Lau Group is that all land belongs to the Tui Nayau but in fact, nobody owns Lakeba or Lau for that matter. (Naipote Vere cited in Gopal, 2014c). 
Was it true that "the only way [a] person can become the holder of the title [Tui Nayau] is when Lau becomes part of Tonga?" (Naipote Vere cited in Gopal, 2014c). Furthermore, was a "chiefly clan in Lau" scheming to move under Tonga's state jurisdiction to claim the Tui Nayau chieftainship? (Naipote Vere cited in Gopal, 2014c). Unfolding in cyberspace were conspiracies fixed to a conviction that there were certain chiefs or "a chiefly clan in Lau" who were pro-Tongan due to their ancestral connections, and they were probably the ones responsible for stirring up Lord Ma'afu's claim on the Lau islands (Naipote Vere cited in Gopal, 2014c).

Which brings me to the curly question of research ethics at the bottom of understanding how publishing the Ma'afu statement is a breach of principled journalism and research practice. Did Iliesa Tora's reporting methods and professional conduct plunge off the sea cliff into the drowning depths of unethical journalism? I believe the correct answer is yes, on two counts documented in the Tonga Media Council General Code for News Media.

Accuracy and Balance

Distinguish clearly between fair comment, conjecture and fact. (Tonga Media Council, 2011).

\section{Privacy}

Publication of information about the private lives or concerns of individuals without their consent is acceptable only if the intrusion relates to legitimate public interest outweighing the normal right to privacy. (Tonga Media Council, 2011).

In terms of accuracy and balance, Tora missed the target by a long shot. The statement he assigned to Lord Ma'afu in his news item was not only foggy as to which category he wanted it to fit in - "fair comment, conjecture and fact" - but to be concise, it did not go in this grouping at all as a joke, a 
hoax, and a prank (Tonga Media Council, 2011). Discernibly, the Tonga Media Council General Code for News Media was established to regulate bona fide "news media," and the "general code" therefore assumed that registered outlets such as the Tonga Daily News of which Tora was the editing director, actually dealt with and published trustworthy news (Tonga Media, Council, 2011). To run with an anecdotal practical joke as a source of confirmable truth, without first checking the statement's factual soundness, was plainly unsafe and unprincipled journalism.

The second clause cited in the Tonga Media Council General Code for News Media outlined the parameters of an individual's privacy when under journalism investigation. Was Lord Ma'afu being investigated for telling a funny story over a drink at a government luncheon? Which goes back to the "accuracy and balance" prescription, and the reality that Iliesa Tora had not properly checked his astonishing story before putting it on internet media (Tonga Media Council, 2011). If he had made a genuine effort to confirm the statement's verity either by contacting Lord Ma'afu, his Ministry office at Lands and Survey, or the Government of Tonga Prime Minister's Office, rather than bypassing Tonga to get a reaction from the Fiji foreign affairs secretary through Fiji Times reporter Anivesh Gopal, he would have figured out there was no big scoop in this fictional wisecrack.

\section{The Alice in Wonderland effect}

Once the fabricated narrative was retold across cyberspace on the internet news sites - BBC, Radio New Zealand International, National Headlines Malta, Fiji Times Online, Fiji Sun Online, New Zealand Kaniva Pacific, Pacific Islands Report, Islands Business, Pacific Islands New Association, and Cook Islands News - the popular reading of Lord Ma'afu as a character in a Fijian journalist's yarn was chronicled and classified as Tongan irredentism. A political science 
expression describing a state mobilising to annex territory administered under a different state, and justifying annexation by history, a recent example of irredentism was the former Ukraine region of Crimea (Chazan, 1991).

On March 16th 2014, the Republic of Crimea shifted out of the Ukraine to become a federal subject of the the Russian Federation. In an irredentist sense, the Russian Federation's justification for annexing the Crimean territory of the Ukrainian state is that historically the disputed land was theirs to begin with. Irredentism can also refer to ethnicdefined claims on areas, provinces, or regions governed by another state, where annexation is validated by the rationale that a specific ethnic group must have a self-governing state (Ambrosio, 2001).

Irredentism struck a chord with staunch Tongan nationalists who bragged openly in social media that the Lau islands had once been a 19th century part of Tonga through the military conquest of the old Tongan chief Ma'afu the Tui Lau, the king of Lau.

Why trade in the reef. Ma'afu live up to the name and take both! (Comment 1 posted in I'm Proud to Be Tongan, 2014).

Understandably Tongan ultra-nationalism met with its Fijian equivalent, which triggered a spiralling effect of trading loud-mouthed cyber threats and insults.

Tonga is a shithole ... nothing there apart from obese humans. (Comment 2 posted in I'm proud to be Tongan, 2014).

There were some who articulated their pro-Tongan irredentism on conventional grounds of "cultural [and historical] ties to Lau" (Comment 2 posted in I'm Proud to Be Tongan, 2014). 
I think the sub-surface mineral rights of the Minerva Reef make it quite a valuable commodity and is a gesture of good faith on behalf of the Tongan Govt. considering the cultural ties to Lau already make it practically Tongan anyway. If the Fijian Govt. were wise they would accept the offer considering Tonga could take Lau by force and the world really wouldn't care since it doesn't involve oil or any other resource critical to the world economy. (Comment 3 posted in I'm Proud to Be Tongan, 2014).

Often, the irredentist argument met with a Fijian counter to leave the past in the past as there was little practical merit for raising histories of territorial conquest in the present.

Easy there, mate ... Maafu days are long gone. (Comment 4 posted in I'm Proud to Be Tongan, 2014).

Interpreting Lord Ma'afu's statement as Tongan irredentism, however, was dead wrong. But it was an erroneous construal of what he presumably said to Iliesa Tora that spread like worldwide web wildfire. If there was a serious point to Lord Ma'afu's banter, then by no means was it ever meant to be taken as a provocation to annex the Lau islands. Rather, it could be interpreted by the manner in which Tonga's Minister for Lands demonstrated tongue-in-cheek provocativeness. In many respects, he was upping the ante for his government and their Fijian counterpart to move into diplomatic talks without putting off the Minerva Reefs discrepancy any longer.

The longer country-to-country dialogue was delayed, the harsher the toll was on Tonga and Fiji relations when it came down to trade and regional cooperation on climate action. Bilaterally, the intersection for these small island developing states and neighbours amounted to commerce between 
Nuku'alofa and Suva, as well as pursuing international climate justice for their region. For all practical purposes, it was not going to plan as efficiently and collaboratively as it could with the Minerva Reefs white elephant standing in the room and blocking the doorway to progress.

Conversely, the truth was readers of Pacific Islands news reports published on the internet were by-and-large global consumers and not critical thinkers, period. The masses behaved accordingly like well-trained customers looking for a quick fix of current events. None so much as Pacific Islanders living in New Zealand, Australia, and America whose geographic detachment from the homeland state prompted their reliance on internet news sites as sources of up-to-date information, which in turn, exacerbated their exclusion from, and unknowingness of, what was actually taking place.

Not that Pacific Islanders in diaspora willingly admitted they knew nothing of day-to-day goings-on in the homeland state. Contrarily, many asserted themselves as fie' poto (know it all) experts of some sort, mouthing off on websites, blogs, and social media pages their overinflated opinions that unwittingly missed the point and failed to connect with the grim reality of people's living environments and meagre livelihoods back in the islands.

As expected for devout readers of internet news, media statements by politicians stirred up momentary reactions that did not comprehend the fundamental differences of having 21 st century regionalism steered by Pacific Island states with the least amount of New Zealand, Australian, and United States meddling in who calls the shots, the West or the Natives. Tonga's foreign policy pivot to the East, China in particular, had zealously pursued Nuku'alofa and Beijing bilateral talks. Pulling back from the West's control and prioritising China as its main development partner culminated into neglect on the home front. The Tu'ivakano regime had flunked at fostering durable and practicable geopolitical 
relations with fellow Pacific Island states, especially its closest neighbour Fiji.

The same could be said of Fiji when consolidating cooperative relations with Tonga. It had not eventuated. After breaking with tradition by refusing to let Australia and New Zealand tell them what to do, the Baimimarama administration formally established the Pacific Islands Development Forum with Fiji as the host country. A regional body that countered the conventional Pacific Islands Forum by precluding Australia and New Zealand from its membership made up of Pacific Island states only, the Fiji led Pacific Islands Development Forum sought development partnerships with non-Western states; Indonesia, the Russian Federation, and Kazakhstan to name a few (Shibuya, 2004). Fiji was as blameworthy as Tonga of undervaluing, and in the long-run, undermining their very relationship.

As Ian Campbell noted in his 2004 essay, Tongan Development and Pacific Island Security Issues, by the standard definition of international security "none of the Pacific Islands states constitutes a security threat" (Campbell, 2004, p. 335). By this, the United Nations Security Council took it for granted that the small island developing states of the Pacific region were too tiny in landmass and population, too poor in resources and money, and too thoroughly Christianised and bound by church dogma to be considered a "military expansionist" threat, or even to conceive of the halfbaked idea themselves (Campbell, 2004, p. 335).

Which was why, in a coconut shell, spreading the Lord Ma'afu statement of annexing the Lau islands for a couple of underwater reefs flirted with the unthinkable. For many indigenous Fijians, it was as if the Tongan Minister for Lands had waltzed out of the nineteenth century and Ma'afu the Tui Lau had returned from the grave. Who would contemplate such a thing when the modern history of regional security in the Pacific meant the Western powers of New Zealand, Australia, and the United States took care of business and 
were allowed "to exercise a paternalistic guardianship of the [security] affairs of Pacific Island states" (Campbell, 2004, p. 336).

This benign state of affairs reflects the fact that the well-being of Pacific Island states is defined more in terms of their relationship (individual and collective) with the major international aid donors than by their relationships with their intra-regional neighbours. While they might in a sense be competitors for aid, they are not competitors for regional resources, and their aspirations therefore do not bring them into conflict with each other. (Campbell, 2004, p. 336).

Campbell's analysis captured Pacific Islands regionalism a decade ago when the "major international aid donors" whose relationships mattered greatly were Western developed countries (Campbell, 2004, p. 336). Back then, it was astute to say security issues for Pacific Island states were indeed a "benign state of affairs" taken as no threat whatsoever to the West. Ten years later, however, seeds of dissent had been propagated and were beginning to sprout.

In Tonga and Fiji's case, their geographic proximity to Australia and New Zealand kept them reasonably Western friendly out of commercial expediency to maintain trade and migration flows to their wealthy neighbouring countries. Contrastingly, Australia and New Zealand's nervousness was sorely amplified by American strategic interests in the Pacific. Tonga's orientation to China coupled with Fiji's preference for closer ties to non-Western states such as the Russian Federation and even the Islamic countries of Indonesia and Kazakhstan, awakened international security issues. Stable foreign relations between Australia and New Zealand in regard to Tonga and Fiji were difficult enough with China's business activity in the Pacific Islands, but dealing with a militarised 
Chinese navy combing the Pacific Ocean was definitely out of the question for America.

Real life in the Pacific Islands revealed that reporters had a habit of selecting discussion snippets to sketch out the difficulties of forging ahead with new regional relations, but neglected to thoroughly explain what the glitches were for their homeland states. More often than not, that part of the calculation was skimmed over and left to a fertile public imagination to do guesswork. Hearsay, statements taken out of context, and the will of journalists to put one-sided spins on stories were force-fed to consumers with zealous conviction.

Here lay the real challenge: How to educate an internet addicted public to measure up quotes and excerpts mounted in news stories with the facts and politics of what was verifiably happening on the ground. Decoding information presented to readers with a grain of salt required ordinary people to know that media narratives which repeat specific messages and meanings are a coercive form of social engineering (Harrison, 2010; Tomba, 2004). News headlines baited consumers to feed off stories calculatingly framed to influence what they believed to be true.

American journalist Robert Parry coined a facetious term which he named the "Alice in Wonderland effect" (Lavelle, 2014). A direct reference to the method by which foreign policy narratives are controlled by neoconservative officials of the United States state department at Washington DC, the "Alice in Wonderland effect" means that fantasy castle-in-thesky tales are powerful to the extreme point that they become an American make-believe reality (Lavelle, 2014).

So for instance you have the catastrophe in Iraq in the last decade, but then the neoconservative narrative is that well yes, after a great invasion, a great successful invasion, there was a problem with the implementation of the occupation but then came the surge, then came near victory, and then Obama 
screwed it all up by withdrawing the troops. So they seem to be able to enforce these narratives, even when they don't really match up with any factual reality. But, they have enough basis and they have enough way of influencing the whole way Washington thinks, so you get this very Alice in Wonderland effect. (Robert Parry cited in Lavelle, 2014).

The power of "this very Alice in Wonderland effect" was the ability to coerce the state into believing that the political narratives driving foreign policy are true, and because the storyline is right the course of action is successful, "even when [it] fails" to achieve any public benefit (Lavelle, 2014).

So even when they fail because they've been so successful in sort of influencing these opinions circles of Washington, they succeed. (Robert Parry cited in Lavelle, 2014a).

The "Alice in Wonderland effect" which played out in present day politics had a strong hand in sculpting and shifting Pacific Islands regionalism towards a new, nonWestern positioning (Lavelle, 2014). Traced to the lingering, obstinate mind-set of Western intervention, it was no diplomatic secret the propaganda machine of the Australian, New Zealand, and American governments asserted superiority over and above China as having the right development apparatus to democratise and modernise the Pacific region's small island developing states (Brown Pulu, 2014a, 2014b).

The will to indoctrinate the masses with a communication inventory of one-eyed half-truths and closed-off untruths was carried out for the most part by media, both traditional and internet outlets. Media did the leg work by regurgitating official messages cultivated and conveyed by Western states, whether the ideas put into public circulation were based on 
provable facts and moral grounds, or not (Harrison, 2010; Tomba, 2004).

The point I want to make is the way in which consumers of internet media got carried away with the Ma'afu statement by staging fuming spats that disputed or supported Tonga's Minister of Lands, fights that flunked at challenging Tora's reporting accuracy and truthfulness, demonstrated an "Alice in Wonderland effect" of the Pacific Islands kind (Lavelle, 2014). From its inception, Iliesa Tora's angle of the Tongan noble desiring to seize territory from the Fijian state repeated a Western fable in which the Tongan nobility were said to be over a century out-of-date in today's world, and thus, politically redundant in a modern democracy.

This would explain why an overwhelming majority of the story's readers and commentators failed to criticise the narrator, Tora himself, and instead blindly accepted that this must be how a Tongan noble thinks and behaves. No one really knew or cared to know who Lord Ma'afu was in real life, and that was the whole point of the fabricated story broadcasted and circulated on the internet. $\mathrm{He}$ was the caricature of a 19th century "conquering usurper" from Tonga "with the title of Tui Lau," which pinpointed precisely what the public wanted to consume and believe about Lord Ma'afu (Mara, 1997, p. 3).

\section{Would the real Ma'afu please stand up?}

If any Fijian national possessed extensive knowledge of Ma'afu the Tui Lau and his place of remembrance in 19th century Fiji, and had put pen to paper by publishing a Lau history of Tonga and Fiji kinships, kingships, and political relations, then it was Ratu Kamisese Mara (Mara, 1997). Renowned for coining the term The Pacific Way during his term as Fiji's first prime minister after gaining independence from Britain in 1970, Mara served in office as his country's premier for over two decades until 1992. He named his 1997 book, The Pacific 
Way: A Memoir, and it was this very regional policy of organising Pacific Island states around the polity, reciprocity, and goodwill relations of The Pacific Way of which Mara became internationally famed and revered for.

Tracing The Pacific Way to an origin moment in history reaches beyond the era of political independence. In 1970, the Fiji islands transformed from a British colony to the Republic of Fiji. In the same year, the Kingdom of Tonga separated itself from the British Western Pacific Territories as a protectorate to become an independent constitutional monarchy. Mara went to great lengths to make a case that Tongan and Fijian history was relevant to understanding The Pacific Way in his book. His opening remarks were the "freedom to move and settle in either territory [Tonga and Fiji] had been exercised for many generations before, and ancient and respected bonds existed between the parties" (Mara, 1997, p. 3).

By the late 1860s, the powerful and charismatic Tongan chief Ma'afu was well established in Lau, with his base at Lomaloma. In 1969 he established the Lau Confederacy, with himself as its acknowledged head with the title of Tui Lau, the first so designated. Ma'afu is often represented as a conquering usurper, but this it to ignore the history of past kinship ties and relationship. A formal Treaty of Friendship between the King of Lakeba and the King of Tonga was not made until 1865, but freedom to move and settle in either territory had been exercised for many generations before, and ancient and respected bonds existed between the parties. Tui Nayau, who signed the treaty for Lakeba, was head of the Vuanirewa clan and also descended through his mother from the Tu'i Tonga and Tu'i Kanokupolu lines - the families of the high chiefs of Tonga. For Tonga, the signatory was Ma'afu, and he was the son of a former Tu'i Kanokupolu but regarded 
by the Vuanirewa as one of their own through descent from an eighteenth-century chief of their lineage. He also had kinship ties with the island of Totoya to which Tui Nayau was vasu (a relationship through the female side conferring special privileges). (Mara, 1997, p. 3).

Seventeen years have passed since Mara's 1997 publication of The Pacific Way: A Memoir, and what has strikingly changed over this time is the impetus of a neoliberal world economy, a benchmark of American military and economic primacy, which has increased the dependency of Pacific Island states on international aid donors. This is a signifier of neo-colonialism in our current times, accentuating the intensified gap between rich developed nations who own the world's wealth and means of economic production, and the world's poorhouse of which small island developing states are classed together on the periphery (Firth, 2000).

Neoliberal economics and its predecessor in the Pacific Islands region, colonialism of the 19th and 20th centuries, has not singly manufactured "a paternalistic guardianship" of the region which Tonga and Fiji share through interwoven kinships and histories (Campbell, 2004, p. 336). Worse than that, it has accelerated the loss of historical memory, especially among the non-chiefly class of highly structured Tongan and indigenous Fijian societies, forcing the common people to adopt Western identity markers of race and national citizenship to define themselves as Tongan or Fijian, but rarely linking to both with an equal amount of knowledge, connection, and valuing.

In Mara's era, the chiefly class fulfilled an important role as human libraries and repositories of history, culture, and identity for their people. The cold hard fact of surviving in the modern Pacific region as a small society made up of kinfolk and clans is that people without history, genealogical connection, and verifiable claims to islands and ocean turn 
into "the nothing people" who simply perish from human memory (Niumeitolu, 2010).

Considering Mara was born into a time when chiefs retained knowledge of who their people were in relation to others inside their heads without the help of a computer to store files is impressive, and an inherited responsibility and skill that ordinary folk like me who have studied in our adult lives to acquire university doctorates cannot and do not perform. It is not our traditional duty. It is not our cultural right to appropriate special tasks from others who have been appointed by the chiefly class. And no matter how grandiosely and pompously Tongan academics and artists, in particular, publicly avow they are orators, acclaimed punake (composers), and tufunga (artisans) of some kind, they do not assume these roles in the traditional sense of how history is recalled by chiefs.

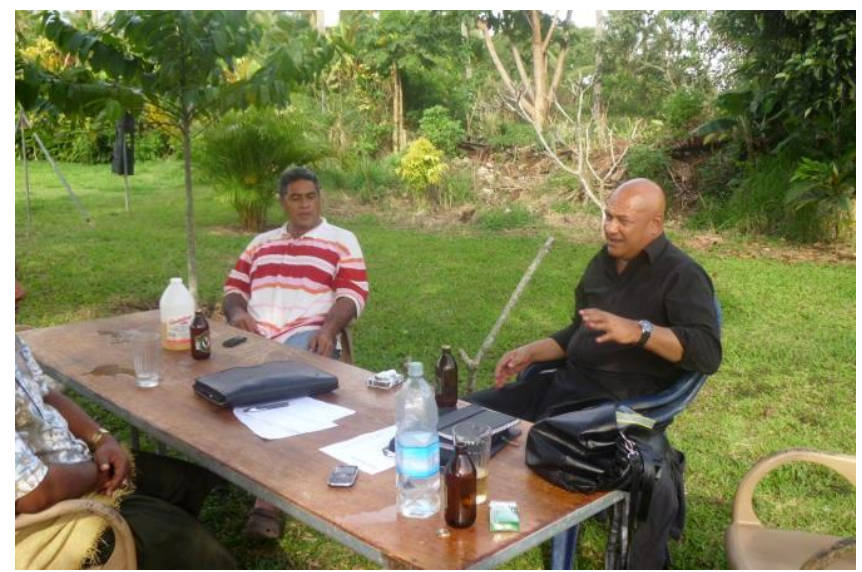

Lord Ma'afu having a beer while waiting for lunch and spinning a yarn to his friends at Vaini, the principal village on his estate in Tonga. Photograph by Teena Brown Pulu, 2011.

It is here at this essay's closing that I must stress one thing. It pains me as a half-cast Tongan with European and 
other mixed blood, a hybrid woman dehumanized by fullblooded Tongan intolerance to know my inferior place on the outer as some kind of cross-culturally contaminated mutation, to labour over writing that the statement Iliesa Tora attributed to Lord Ma'afu - "In good faith I will propose to the Minister of Foreign Affairs in Fiji that they can have Minerva Reef and we get Lau in return" - was a joke. Personally, I would think that staunch Tongan and Fijian nationalists obsessed with publicly parading cultural authenticity and steadfast loyalty to their homeland states would get that. But the vast majority did not. And that makes me question how reliable is their understanding of Tonga and Fiji relations, especially when it comes to their chiefly class. To end, it is only right that Lord Ma'afu has the last word.

Tonga and Fiji, our countries have been put next to each other on this earth for a reason. We are close neighbours and relatives. And that is how I see us.

\section{Lord Ma'afu}




\section{References}

Ambrosio, T. (2001). Irredentism: Ethnic Conflict and International Politics. Westport, Connecticut, United States: Praeger Publishers, Greenwood Publishing Group Incorporated.

Anonymous Correspondent 1. (2014). Email correspondence to Teena Brown Pulu, Auckland, New Zealand, July 9.

Anonymous Correspondent 2. (2014). Facebook comment to Teena Brown Pulu, Auckland, New Zealand, July 10.

Brown Pulu, T. (2014a). Off the Deep End: Tonga's Continental Shelf Politics. Te Kaharoa: The e-Journal on Indigenous Pacific Issues, 7 (1): 173-244.

Brown Pulu, T. (2014b). Clash of Civilisations: Tonga and the West. Te Kaharoa: The e-Journal on Indigenous Pacific Issues, 7 (1): 254-344.

BBC News. (2014). Tonga wants to swap islands with Fiji. BBC News, London, United Kingdom, July 4. Retrieved from

http://www.bbc.com/news/blogs-news-from-elsewhere-28160699

Campbell, I. (2004). Tongan Development and Pacific Island Security Issues. In The Asia Pacific: A Region in Transition, edited by J. Rolfe. Honolulu: Asia-Pacific Center for Security Studies, Pp. 335-354.

Chazan, N. (Ed.) (1991). Irredentism and International Politics. Boulder, Colorado, United States: Lynn Rienner Publishers.

Gilbert, C. (2014). Tonga proposes land swap with Fiji. Radio New Zealand International, Auckland, New Zealand, July 4. Retrieved from

http://www.radionz.co.nz/international/programmes/datelinepacific/audi o/2602187/tonga-proposes-land-swap-with-fiji

Gopal, A. (2014a). 'Give up Lau.' Fiji Times Online, Suva, Fiji, July 3. Retrieved from

http://www.fijitimes.com/story.aspx?id=273246

Gopal, A. (2014b). Lau 'in the dark.' Fiji Times Online, Suva, Fiji, July 4. Retrieved from

http:/ / www.fijitimes.com/story.aspx?id=273333

Gopal, A. (2014c). In exchange for Lau. Fiji Times Online, Suva, Fiji, July 6. Retrieved from

http://www.fijitimes.com/story.aspx?id=273547

Graue, C. (2014). Progress in Fiji under Bainimarama regime, says Tonga's democracy leader. Radio Australia: Pacific Beat: Australian Broadcasting Corporation, Melbourne, Australia, July 8. Retrieved from 
http://www.radioaustralia.net.au/pacific/radio/program/pacificbeat/progress-in-fiji-under-bainimarama-says-tongas-democracyleader/1339508?autoplay $=1339532$

Firth, S. (2000). The Pacific Islands and the Globalization Agenda. The Contemporary Pacific, 12 (1): 178-192.

Harrison, G. (2010). Neoliberal Africa: The Impact of Global Social Engineering. New York: Zed Books.

I'm Proud to Be Tongan. (2014). Facebook Page of I'm Proud to Be Tongan, Auckland, New Zealand, July 4. Retrieved from

https://www.facebook.com/photo.php?fbid=949279901755723\&.set=pb. 1 $\underline{50681164948938 .-2207520000.1404913060 .8 * t y p e=18 \text { theater }}$

Latu, K. (2014). Tonga seeks ownership of Fiji's Lau group. New Zealand Kaniva Pacific, Auckland, New Zealand, July 5. Retrieved from

http://www.nzkanivapacific.co.nz/2014/07/tonga-seeks-ownership-fijislau-group/\#.U7i5w7FWnTp

Lavelle, P. (2014). Cross Talk: Chaos Incorporated with Robert Parry, Jim Lobe, and Francis Boyle. Russia Today, Moscow, Russian Federation, July 3. Retrieved from

https://www.youtube.com/watch?v=WUeRXmNymck\&feature=youtube_gd ata_player

Lord Ma'afu. (2014). Personal correspondence to Teena Brown Pulu, Nuku'alofa, Tonga and Auckland, New Zealand, July 7.

Mara, K. (1997). The Pacific Way: A Memoir. Honolulu: University of Hawai'i Press.

Mead, M. (1928). Coming of Age in Samoa: A Psychological Study of Primitive Youth for Western Civilization. New York, United States: William Morrow and Company.

Ministry of Information and Communications. (2014). National Launching of the "Orange Day." Tonga Government Portal, Nuku'alofa, Tonga, June 25. Retrieved from

http://www.mic.gov.to/news-today/press-releases/4997-nationallaunching-of-the-qorange-dayg

Moala, K. (2014). Exchanging Minerva for the Lau Islands - a geopolitical joke or serious? Pacific Politics: Pacific news and analysis bought to you by the Pacific Institute of Public Policy, Port Vila, Vanuatu, forthcoming.

Naidu, R. (2014). Letter to the Editor: Democracy and Akilisi. Tonga Daily News, Nuku'alofa, Tonga, July 7. Retrieved from

http:/ /www.tongadailynews.to/?p=7215 
Niumeitolu, V. (2010). Tongan American Creation Myth. University of Utah, Salt Lake City, United States, February 11. Retrieved from https://www.youtube.com/watch?v=DAGFRvkLQnE

Noumea Communique. (2014). 2nd Oceania 21 Conference, Noumea, New Caledonia, July 2.

Radio New Zealand. (2014). Tonga proposes land swap with Fiji. Radio New Zealand International, Auckland, New Zealand, July 4. Retrieved from

http://www.radionz.co.nz/international/pacific-news/248955/tongaproposes-land-swap-with-fiji

Shibuya, E. (2004). The Problems and Potential of the Pacific Islands Forum. In The Asia Pacific: A Region in Transition, edited by J. Rolfe. Honolulu: Asia-Pacific Center for Security Studies, Pp. 102-114.

Tonga Daily News. (2014a). Lord Ma'afu wants Lau for Minerva Reef. Tonga Daily News, Nuku'alofa, Tonga, July 3. Retrieved from

http://www.tongadailynews.to/?p=7156

Tonga Daily News. (2014b). Pohiva applauds Bainimarama. Tonga Daily News, Nuku'alofa, Tonga, July 3. Retrieved from

http://www.tongadailynews.to/?p=7160

Tonga Daily News. (2014c). End the violence. Tonga Daily News, Nuku'alofa, Tonga, June 26. Retrieved from

http://www.tongadailynews.to/?p=6966

Tonga Daily News. (2014d). Tonga marks Orange Day. Tonga Daily News, Nuku'alofa, Tonga, June 25. Retrieved from

http://www.tongadailynews.to/?p=6963

Tonga Media Council. (2011). Tonga - Media Council General Code for News Media. Tonga Media Council, Nuku'alofa, Tonga, October 24. Retrieved from

http://www.mediawise.org.uk/tonga-2/

Tomba, L. (2004). Creating an Urban Middle Class: Social Engineering in Beijing. The China Journal 51: 1-26.

Tora, I. (2014a). Nobles hold the key says Lord Ma'afu. Tonga Daily News, Nuku'alofa, Tonga, June 27. Retrieved from

http:/ / www.tongadailynews.to/?p=6985

Tora, I. (2014b). Twitter: Iliesa Tora. Twitter, Nuku'alofa, Tonga, July 9. Retrieved from

https://twitter.com/ili_tora 